\title{
A Case Study of the Role of a School in a Community Undergoing Rapid Gentrification
}

\author{
Carol Isaac \\ Mercer University-Atlanta \\ Arla Bernstein \\ Mercer University-Atlanta \\ Joseph Balloun \\ Mercer University-Atlanta
}

Atlanta, one of the fastest gentrifying cities in the United States, is comprised of neighborhoods near the city center amid urban wealth that suffer from severe poverty and low literacy rates. One neighborhood school has been ranked as one of the lowest in the state. To combat decades of underperformance, Atlanta Public Schools (APS) created an initiative that has helped bring this community together. The purpose of this case study, using interviews and survey data with thematic content analysis, was to understand the role of school district leadership in the creation of a new framework, replacing the original public school with a long record of failure.

Keywords: gentrification, education, reform, Atlanta, case study, failing schools

\section{INTRODUCTION}

Atlanta is one of the fastest gentrifying cit in the United States (Brummet \& Reed, 2019). Neighborhoods close to the center of urban wealth endure excessive poverty and unemployment in conjunction with low literacy rates (Markley et al., 2020). There is an "Atlanta Paradox" where the "Black Mecca" has the most Black millionaires and impoverished children at the same time (Allums et al., 2021; Markley et al., 2020).

During the 1960's in this neighborhood, integration saw the plummeting of Black-owned businesses, and financial redlining caused resident flight (Annie Casey Foundation, 2019). Neighborhood resources changed as new "hip and cool" services displaced Black-owned local shops (Quastel, 2009, p. 705). While legacy residents like improved services, the costs are many, including monetary costs of residential mobility, rising housing costs, intercultural conflicts, crime, increasing poverty in concentrated areas, and loss of established community ties (Branic \& Hipp, 2018; Brown-Saracino, 2016; Rousseau, 2009). Proponents of gentrification use the term regeneration, with goals of deconcentrating poverty, reducing condemned properties, and the social blending of underprivileged renters and new affluent residents (Kearns \& Mason, 2013; Watt \& Smets, 2017). However, gentrification often displaces marginalized and 
vulnerable communities (Mennis et al., 2013; Steinmetz-Wood et al., 2017), often associated with the rentgap model (Smith, 1996).

Despite inferences about the benefits of gentrification, children of marginalized residents do not enjoy these benefits, and overwhelmed school staff may not be able to offer needed resources (Quarles \& Butler, 2018). With the addition of charter schools, a rhetoric of school choice can create distorted beliefs that can actually undermines a neighborhood (Makris, 2018). Research shows that gentrification expands school choice options with the in-migration of wealthier White households within these Black communities (Pearman \& Swain, 2017). Also evidence supports that schools within gentrified communities create incentives to enhance attendance at failing schools (Billings et al., 2018). These actions create racial and socioeconomic tensions within gentrified communities.

The environmental sustainability that gentrification creates is considered a detriment to "social sustainability," as "the desire for regeneration has led to the promotion of gentrification and the subsequent displacement of poorer residents" (Hanlon, 2009, p. 135). Gentrification shifts the terrain of blue collar job opportunities as global communities promote FIRE employment (finance, insurance, and real estate) (Curran \& Hamilton, 2018; Curran \& Hanson, 2005). Because of this, one of the foremost consequences of gentrification is the displacement of working-class residents as the community's social identity experiences a loss of a sense of place (Glass et al., 1964). Davidson (2008) expanded the term displacement including indirect displacement of economic, community and neighborhood resources (Davidson, 2008). Within Atlanta, community identity has suffered a "loss of place" as long-time residents lost "both power and belonging in their neighborhoods" (Martin, 2007, p. 623).

Historically, these neighborhood schools have been ranked as some of the lowest in the state with large classes, high teacher turnover, aging structures and transient families (Martin, 2007). To combat perennial underperformance, Atlanta Public Schools (APS) created a new initiative that is "regenerating" the community in the face of gentrification (Kearns \& Mason, 2013; Watt \& Smets, 2017). The purpose of this case study was to understand the role of school district leadership in the creation of a new framework, replacing the original public school with a record of failure. This case study highlights the important role of education in the regeneration of an urban community within the intersection of housing and education. It will also illustrate how a school became a symbol of regeneration rather than gentrification as communities "organize at the speed of trust" (Isaac et al., 2020, p. 3384). This study examined a role of a school on remediating the destruction of "place-making activities" (Davidson, 2009, p. 229). The research question for this study is "How did the school district improve the process of a rapidly gentrifying community? The findings of this unique case study may inform administrator and stakeholders' decisionmaking in marginalized neighborhoods.

\section{A School as a Symbol}

Symbolic interactionism explores human interaction from a social psychological perspective and is an interpretive theoretical framework "that addresses how society is created and maintained through repeated interactions among individuals" (Carter \& Fuller, 2016, p. 932). Therefore, how language is used is integral on how humans ascribe meaning through social interactions (Blumer, 2009). Individuals use language as a symbol creating shared understandings within their interactions. Carter and Fuller (2016) suggest, "behavior is simply an actor's idiosyncratic way of reacting to an interpretation of a situation" (p. 933). We utilized symbolic interactionism in conjunction with a pragmatic paradigm, with both qualitative and quantitative approaches for this case study. The meaning of a school within a community is dependent on the meaning ascribed to it by individuals, as participants within this community constructed symbolic meaning to the interactions between themselves, administrators and their children.

\section{Method}

The Institutional Review Board at Mercer University approved this study. The purpose of the original study was to understand the gentrification processes within of this neighborhood by examining the interactive processes among leaders, including residents, politicians, and other stakeholders (Isaac et al., 2020). Initially this case study used a purposive sample of resident leaders, politicians and other 
stakeholders collecting data via focus groups and interviews between October 2018 and May 2019. This sample included 17 African Americans and three Whites and represented data from 12 resident leaders and eight community leaders, including three elected officials from the City of Atlanta, four faculty members from a nearby college and one stakeholder from a non-profit instrumental in local development. From those conversations, stakeholder-participants requested a survey of residents to validate those findings. From the qualitative data, we designed a survey that were hand carried to block parties, community meetings and forums in the summer and fall of 2019. We analyzed descriptive responses from 63 residents. The interview and survey questions queried participant motivation, problems, and strategies for the community.

Using NVivo for data organization and retrieval, qualitative data was analyzed using inductive and deductive thematic analysis with a focus on educational processes and language (Boyatzis, 1998; Fereday $\&$ Muir-Cochrane, 2006). We used member checking, an audit trail, external review and triangulation of data sources for verification of findings (Glesne, 2015). The survey was derived from a problem list identified in the qualitative data analysis, and this data underwent analysis using descriptive statistics with SPSS.

\section{Results}

The findings from the qualitative analysis resulted in 111 initial codes of which 43 identified "problems" within the community (Table 1). The descriptive survey based on the 43 problems resulted in means and standard deviations for 11 Likert scale problem descriptor variables and frequencies of 32 categorical variables. The Likert questions were based on the qualitative responses and included items such as gentrification, unemployment, housing, food desert, socioeconomic status, crime, communication challenges, trust, education and transportation. Residents ranked Likert items, "housing" (8.26, SD 2.26) the highest and ranked "education" (6.23, SD 2.80) as one of the lowest (Table 1).

\section{TABLE 1}

\section{MEANS AND STANDARD DEVIATIONS FOR PROBLEM DESCRIPTORS FOR SURVEY; TOTAL WORD PERCENTAGES FOR QUALITATIVE INTERVIEWS AND FOCUS}

\begin{tabular}{lllll}
\hline $\begin{array}{l}\text { Items using 10 point Likert scale: } \\
\text { 1="not a problem"\&10="huge } \\
\text { problem" }\end{array}$ & $\mathrm{N}$ & Mean & $\begin{array}{l}\text { Std. } \\
\text { Deviation }\end{array}$ & $\begin{array}{l}\text { Total word \% for coded } \\
\text { strategies for problems in } \\
\text { qualitative study }\end{array}$ \\
\hline Housing & 61 & 8.26 & 2.26 & 2.71 \\
Food desert & 59 & 7.93 & 2.9 & 1.18 \\
Unemployment & 54 & 7.69 & 2.20 & 4.46 \\
Gentrification & 60 & 7.18 & 2.94 & 1.2 \\
Rich vs poor & 59 & 7.12 & 2.83 & 1.86 \\
Crime & 54 & 6.87 & 2.26 & 4.29 \\
Water & 63 & 6.40 & 2.98 & 0 \\
Lack of communication & 55 & 6.27 & 2.67 & 12.38 \\
Education & 62 & 6.23 & 2.80 & 13.1 \\
Lack of trust & 54 & 6.22 & 2.69 & 4.77 \\
Transportation & 62 & 5.94 & 2.81 & 0 \\
\hline Categorical items & & & & \\
\hline People giving up & 63 & .60 & .49 & 0 \\
Criminal history when looking for a job & 63 & .60 & .49 & .42 \\
Affordable housing & 63 & .57 & .50 & 1.56 \\
Theft & 63 & .57 & .50 & 0 \\
Homeless & 63 & .56 & .50 & .99 \\
Lack of job opportunities & 63 & .56 & .50 & .16 \\
Housing costs & 63 & .54 & .50 & 1.89 \\
Substance abuse in community & 63 & .52 & .50 & 0 \\
\hline
\end{tabular}




\begin{tabular}{lllll}
\hline Lack of neighborhood technology & 63 & .44 & .50 & 0 \\
Drug dealers & 63 & .43 & .50 & 0 \\
Displacement of residents & 63 & .41 & .50 & .64 \\
Lack of resources & 63 & .41 & .50 & 1.08 \\
Political corruption & 63 & .38 & .50 & 5.94 \\
Code enforcement & 63 & .38 & .50 & 3.1 \\
Developers investors & 63 & .38 & .50 & 2.61 \\
Cultural differences & 63 & .37 & .49 & 1.59 \\
Eviction & 63 & .35 & .48 & .11 \\
Absentee landlords & 63 & .35 & .48 & .57 \\
Poor credit & 63 & .35 & .48 & .11 \\
City of Atlanta & 63 & .35 & .48 & 10.33 \\
Lack of family support & 63 & .35 & .48 & .38 \\
Blight & 63 & .33 & .48 & .96 \\
Conflict between residents & 63 & .33 & .48 & 8.4 \\
Race inequity & 63 & .30 & .46 & .61 \\
Incorrect media coverage & 63 & .30 & .46 & .52 \\
Rental housing & 63 & .30 & .46 & .57 \\
Squatters & 63 & .27 & .45 & 0 \\
Violent crime & 63 & .27 & .45 & .05 \\
Legal problems & 63 & .25 & .44 & 1.03 \\
Police & 63 & .25 & .44 & 6.07 \\
Younger residents millennials & 63 & .25 & .44 & 3.85 \\
Streets not safe to walk & 63 & .02 & .13 & .24 \\
\hline Total \% of coded words for strategies for & & & & $100 \%$ \\
each problem & & & & \\
\hline
\end{tabular}

In conjunction with the survey findings, the analysis of the qualitative data illustrated that the available strategies for the 43 identified problems were few in context. Strategies for these problems became important as often focus groups and interviews ended with "What's next?"; residents wanted solutions rather than "problems." The amount of text linked to strategies for education illustrated a key contextual area that seemed to be working in this community despite gentrification. Using NVivo's matrix coding feature, the total number of coded words (3993 or 13.1\%) for "problems" and "strategies" indicated more words for "education" than any code. Because the qualitative narrative from resident and political leaders illustrated the most "strategies" for combatting the difficult challenges in this community, the focus of the results section became how "Goodrun," the new elementary school, became a symbol for community change.

\section{Replacing a Failing School}

Residents were proud of the implementation of "Goodrun school," "their" new charter school through a partnership with APS. The elected official from Atlanta Public Schools, Esther, described how this school was the ranked lowest of 1,254 in the state because the poverty was so deep in the neighborhood that, if we did not have a plan to turn over our most failing schools, [the state was] going to intervene." This "failing" school had been a problem for decades, and the school district needed change. APS believed they could not stay within the parameters of the state public school system or face failure; they had no choice but to do things differently. The APS elected official wanted the neighborhood students to have a "state of the art" facility, but the low enrollment made it vulnerable to closure. As long as this was the case, no one wanted to "invest millions of dollars in a school that could potentially close the following year." The residents now have a five million dollar new elementary school. Despite local academic skepticism, residents described a new school that was working for the neighborhood, including class sizes reduced by half because fewer state restrictions. Although initially residents opposed this initiative, Esther described how volunteer 
teachers and even the superintendent went door-to-door to obtain support from a neighborhood with $80 \%$ rental and $70 \%$ vacant property:

"I need for you to come to this meeting tonight;" We had infographs, because when we talked about the numbers, the numbers wasn't resonating. So, I asked the district to create an infograph showing a class of 25 fifth graders and literally coloring in five students that showed out of every 25 fifth graders, only five are coming out reading on grade level.

The infographs were necessary to convince community members to accept this charter school initiative. Because of a lack of access to technology in this neighborhood, this required school officials physically to walk door-to-door to talk to residents. Change was not easy in a transient neighborhood with so much rental and vacant property.

\section{Change From Within}

This new school was run by someone who was from the community that wanted to create an education incubator that, "wants to give back to his own community." This community is ravaged by distrust of outside stakeholders, including the City of Atlanta. The need for "knowing the community" became evident when the elected councilperson from the district discussed how the City of Atlanta had hired a facilitator to alleviate another dilemma with funding. The community had so much chronic conflict that people walked out, and the facilitator "just walked away. (...) I'm spending money, I'm spending time. I'm trying to pull this all together, I can't do it." Creating a process for communicative solutions is a challenge, and in this case study, educational leaders implemented the strategy of someone within who "knows the community" that promoted implementation.

As opposed to other gentrifying communities that have multiple competing charter schools, APS initiated an affordable housing policy to protect marginalized residents because of Goodrun's excellence, accessibility and affordability in this community. The official from APS described the dilemma.

I had members from all over that lived on the other side of [neighborhood boundary] that were residents of [the neighborhood] and say yes, I'm a doctor and my husband is an investment banker, we live in this community, we want to be able to send our children to school versus me paying private tuition to send my child to [private school]. And their child is- we have, they're young families, [they say] "I want that opportunity, I deserve that opportunity. I live in this community as anyone else."

APS reserved places for all children of residents of this community. This is different from the traditional private school model where parents pay private tuition. The partnership allowed APS the flexibility it needed to create school access and equity; however, the convergence between housing and education was evident.

\section{Everything Is About Housing}

Community leaders described how the community was promoting "affordable housing" because of Goodrun. Frederick, a former legislator, explained "we right now are paying \$7.1 million dollars for 120 apartments [in the neighborhood]." He knew that the apartment owners were taking advantage of the community, but in the long-run, the nineteen families impacted need to stay in the area because, "if our attendance rate don't improve at Goodrun, if they do go, half of the folks at Goodrun would be from across town somewhere." Not only does this speak of their perception of the excellence of this new school, but describes a community dedicated to having children and families stay in the neighborhood. APS's affordable housing policy motivated residents to stay in the community. This community with a history of transience is becoming a place of belongingness for residents; however, there are skeptics about the longterm implications of this transition. 


\section{Academic Skeptics}

The debate for and against charter schools in gentrifying neighborhoods is evident in the scholarship (Pearman \& Swain, 2017). The focus group of academics echoed that skepticism as "obviously with APS now giving the entire cluster to the charter system." They spoke of plans for other schools in the area to become charter schools. The academics understood and respected that APS did not want to lose control of students' education to the state. One of the focus group members was even somewhat embarrassed that they had a child at the school, but still disliked,

APS to say we can't help these children anymore, (...) from a morality standpoint and for the morale of the citizens, that's another institution that has given up on these children in the community. Because if APS is now a charter system, APS can change the way that it functions for those schools. APS does not change the way they function for the schools. APS continues to take the tax dollars for those schools, yet allows the management of the schools to go to a charter system. And again, it is helpful in changing the way the school looks for other people that you're trying to entice to come to the community, not necessarily for the children that actually attend the school.

These academics know the literature that new services frequently disenfranchise the marginalized, as they "aren't for them." However, they understand the irony that Goodrun is now a school they want their children to attend because an "economic engine" cannot have "your educational system failing- so who wants to move here from a top 25 state in education and have their children to go to a school here?" The City of Atlanta has responsibilities to enhance the global community to "reach that economic space." APS is challenged by the fact that there are "people moving into or are renting those apartments and not living there just to have the address just so their children can go there." Goodrun is a driver of the economic engine that represents change in this community. Although in many aspects, APS has made sure that this unique model is accessible by all socio-economic and ethnic groups, there have to be protections that must be sustained for long-term equity.

\section{Discussion}

Recurrent interactions create and maintain symbols for individuals (Carter \& Fuller, 2016). The creation of Goodrun School became a symbol of hope within a community despite a multitude of competing interconnecting problems evident in the literature: rising housing costs, socio-economic issues, displacement, and cultural conflicts (Branic \& Hipp, 2018; Brown-Saracino, 2016). APS had tried for decades to increase the attractiveness of this failing school without success, and so initiated a charter school partnership with less regulatory restrictions (i.e. class sizes) creating a more responsive educational environment for students (Quarles \& Butler, 2018). APS had to create a housing policy to protect marginalized children of current residents so they could enjoy the benefits that accompany gentrification. Within this community, gentrification caused an influx of higher income households without a dramatic increase of school options as other communities (Pearman \& Swain, 2017). However, this creates a competition for educational resources raising tensions within socio-economic strata that required legislative protection for marginalized students.

Like other communities, anti-charter rhetoric is present that can undermine community efforts (Makris, 2018). While debate abounds about the inclusion and financing of charter schools, in this community it became a symbol of change. Under the umbrella of APS, this school enhanced the socio-economic equity and was a mitigating factor for social displacement. The "social sustainability" of regeneration within gentrified communities has created moral dilemmas for those in-migrating into the community, sometimes reflecting an "obscene" implicit intention as residents are "rendered homeless" as altruistic urban professionals ride their bicycles to work (Quastel, 2009, p. 719). Preventing displacement to change gentrification into a kinder "regeneration" is an important opportunity to avoid the driving out of the poor from a "liveable," sanitized space as supported by New Urbanism (Quastel, 2009). Education becomes the 
true economic engine to prepare a global workforce prepared for FIRE employment (Curran \& Hamilton, 2018; Curran \& Hanson, 2005).

Finally, besides the displacement of working-class residents, one of the foremost consequences of gentrification is the displacement of a community's social identity from a loss of a sense of place (Glass et al., 1964). The lack of economic and neighborhood resources caused by indirect displacement, spurs unrest and community conflict (Davidson, 2008). It is evident by this research (Isaac et al., 2020), that incumbent residents have experienced a loss of place and belonging (Martin, 2007). The building of a neighborhood school may illustrate the beginning of healing within this community.

Limitations of this study include that measures of success may be inappropriate for the social context of the school district as "school failure" is often defined by the wealthier strata; however, by examining challenges for marginalized socioeconomic communities undergoing rapid redevelopment, this study may inform educational administrators decisions. Residents are committed to educational excellence although the charter school movement is a point of contention within the academic community. However, despite the controversy, Goodrun was a symbol of hope for this community.

\section{REFERENCES}

Allums, C.A., Markley, S.N., \& Hafley, T.J. (2021). “A better place to be”? Black Mecca, White democracy, and the contradictions of neoliberal cityhood in Atlanta's Black suburbs. Journal of Urban Affairs, pp. 1-15. https://doi.org/10.1080/07352166.2020.1854612

Annie Casey Foundation. (2019). Atlanta civic site. Retrieved June 13, 2019, from https://www.aecf.org/work/community-change/civic-sites/atlanta-civic-site/

Billings, S.B., Brunner, E.J., \& Ross, S.L. (2018). Gentrification and failing schools: The unintended consequences of school choince under NCLB. Review of Economics \& Statistics, 100(1), 65-77. https://doi.org/10.1162/REST_a_00667

Blumer, H. (2009). Symbolic interactionism: Perspective and method. University of California Press.

Boyatzis, R.E. (1998). Transforming qualitative information: Thematic analysis and code development. Sage Publications.

Branic, N., \& Hipp, J.R. (2018). Growing pains or appreciable gains? Latent classes of neighborhood change, and consequences for crime in Southern California neighborhoods. Social Science Research, 76, 77-91. https://doi.org/10.1016/j.ssresearch.2018.08.002

Brown-Saracino, J. (2016). An agenda for the next decade of gentrification scholarship. City \& Community, 15(3), 220-225. https://doi.org/10.1111/cico.12187

Carter, M.J., \& Fuller, C. (2016). Symbols, meaning, and action: The past, present, and future of symbolic interactionism. Current Sociology, 64(6), 931-961. https://doi.org/10.1177/0011392116638396

Fereday, J., \& Muir-Cochrane, E. (2006). Demonstrating rigor using thematic analysis: A hybrid approach of inductive and deductive coding and theme development. International Journal of Qualitative Methods, 5(1), 80-92.

Glass, R., Hobsbawm, E.J., \& Pollins, H. (1964). London aspects of change. Macgibbon \& Kee.

Glesne, C. (2015). Becoming qualitative researchers: An introduction (2nd ed.). Longman.

Hanlon, B. (2009). A typology of inner-ring suburbs: Class, race, and ethnicity in US suburbia. City \& Community, 8(3), 221-246. https://doi.org/10.1111/j.1540-6040.2009.01287.x

Kearns, A., \& Mason, P. (2013). Defining and measuring displacement: Is relocation from restructured neighbourhoods always unwelcome and disruptive? Housing Studies, 28(2), 177-204. https://doi.org/10.1080/02673037.2013.767885

Makris, M.V. (2018). The chimera of choice: Gentrification, school choice, and community. Peabody Journal of Education, 93(4), 411-429. https://doi.org/10.1080/0161956x.2018.1488394

Markley, S.N., Hafley, T.J., Allums, C.A., Holloway, S.R., \& Chung, H.C. (2020). The limits of homeownership: Racial capitalism, Black wealth, and the appreciation gap in Atlanta. International Journal of Urban \& Regional Research, 44(2), 310-328. https://doi.org/10.1111/1468-2427.12873 
Martin, L. (2007, May). Fighting for control: Political displacement in Atlanta's gentrifying neighborhoods. Urban Affairs Review, 42(5), 603-628. https://doi.org/10.1177/1078087406296604

Mennis, J., Dayanim, S.L., \& Grunwald, H. (2013). Neighborhood collective efficacy and dimensions of diversity: A multilevel analysis. Environment \& Planning A, 45(9), 2176-2193. https://doi.org/10.1068/a45428

Pearman, F.A., III, \& Swain, W.A. (2017). School choice, gentrification, and the variable significance of racial stratification in urban neighborhoods. Sociology of Education, 90(3), 213-235.

Quarles, B., \& Butler, A. (2018). Toward a multivocal research agenda on school gentrification: A critical review of current literature. Peabody Journal of Education, 93(4), 450-464. https://doi.org/10.1080/0161956x.2018.1488399

Rousseau, M.A.X. (2009). Re-imaging the city centre for the middle classes: Regeneration, gentrification and symbolic policies in 'loser cities'. International Journal of Urban \& Regional Research, 33(3), 770-788. https://doi.org/10.1111/j.1468-2427.2009.00889.x

Smith, N. (1996). The new urban frontier: Gentrification and revanchist city. Rouledge.

Steinmetz-Wood, M., Wasfi, R., Parker, G., Bornstein, L., Caron, J., \& Kestens, Y. (2017). Is gentrification all bad? Positive association between gentrification and individual's perceived neighborhood collective efficacy in Montreal, Canada. International Journal of Health Geographics, 16, 1-8. https://doi.org/10.1186/s12942-017-0096-6

Watt, P., \& Smets, P. (2017). Social housing and urban renewal: A cross-national perspective. Emerald Publishing Limited. 